\title{
A Comparative Analysis of People's Views on Future Policies for Older People
}

\author{
MAŠA FILIPOVIČ HRAST *
}

Faculty of Social Sciences

\section{AH SHOYEN}

Centre for Welfare and Labour Research

Norwegian Social Research (NOVA) Health and Welfare Studies Oslo, Norway

\section{TATJANA RAKAR}

Faculty of Social Sciences

University of Ljubljana

Ljubljana, Slovenia
Original scientific paper

UDK: 364.013-053.9

University of Ljubljana doi: 10.3935/rsp.v26i2.1585

Ljubljana, Slovenia

Received: August 2018

Population ageing is one of the biggest structural changes currently affecting the development of all European welfare states. Countries have tackled these changes in different ways. In reaction to the global economic crisis, many countries have reformed their old-age pension systems and how they address the rising care needs. These changes are bound to influence how citizens view the welfare state's prospects and what they expect from it in the future in relation to policies for the elderly. The paper explores citizens' attitudes and expectations with regard to the future division of responsibilities for the provision of welfare for the elderly. The basis for the analysis is data gathered in a comparative European project adopting coordinated democratic forums as a methodology. We use the participants'views and expectations - as well as the reasons and arguments they presented - to shed light on the factors likely to shape future elderly care and old-age pension policies. We analyse four countries - Norway, Slovenia, Germany and the UK - belonging to four different welfare regimes and focus on the division of responsibilities between the state, the market and the family and the differences and similarities in priorities and subsequent arguments put forward in the four countries.

Key words: older people, welfare state, pensions, care for the elderly.

\section{INTRODUCTION}

Population ageing is one of the biggest structural changes currently affecting the development of most European welfare states. It poses challenges for the sustainability of the welfare state in several sub-areas of social policy, including the protection of the welfare needs of the growing elderly population. To address the issue of

\footnotetext{
* Maša Filipovič Hrast, Faculty of Social Sciences / Fakulteta za družbene vede, University of Ljubljana / Univerza v Ljubljani, Kardeljeva ploščad 5, 1000 Ljubljana, Slovenia / Ljubljana, Slovenia, masa.filipovic@ fdv.uni-lj.si
} 
long-term economic sustainability driven by population trends, many countries have reformed their old-age pension systems and developed new elderly care policies. Core aims are to enable countries to meet the future costs of the increasing share of retirees and demands for a higher volume and quality of elderly care services (e.g., Ebbinghaus and Whiteside, 2012; Ebbinghaus, 2011; Immergut et al., 2007; Mali, 2017; Pavolini and Ranci, 2008; Rostgaard and Zechner, 2012).

Since the elderly typically rely on income transfers to maintain themselves economically and may also depend on care services to manage everyday life (Esping-Andersen and Myles, 2006), population ageing raises questions about the division of responsibilities. In other words, who should be responsible for ensuring the elderly's welfare needs are covered? More specifically, income transfers to the elderly may be public, occupational or private, or a combination of all three. Elderly care may be provided by the family, the state, third-sector actors or the market (Saraceno and Keck, 2010; Bettio and Plantenga, 2004). With regard to care, the picture is further complicated by the issue of funding, which may be (partially) public even if care is provided by non-public actors (i.e., family, third sector or market actors). Some authors point out the shifting responsibility for welfare and withdrawal of the state and the expanding role for the market, the family and civil society (e.g. Mau, 2015). However, it is less clear how people view the welfare state's future and its role in covering the elderly's welfare needs.

To understand where European welfare states are likely to go in the decades to come, it is important to grasp how ordinary people perceive, reason about and relate to the structural and institutional changes occurring in recent decades. What are citizens' expectations with regard to protecting the elderly's welfare needs in the future? How do they justify these expectations? With the help of qualitative data, this article explores ordinary citizen's perceptions, opinions and expectations concerning how the division of responsibility for elderly people's welfare will develop in the future. We are particularly interested in the extent to which countries' changing welfare mixes -i.e., the new ways in which responsibilities for elderly welfare are divided among different actors in society (Ascoli and Ranci, 2002; Svetlik and Evers, 1993; Wintersberger et al., 1987) - are in line with ordinary people's ideas and values.

A substantial body of literature demonstrates that people's attitudes and ideas regarding the future matter for explaining welfare state change (for an overview, see Svallfors, 2010). Most studies of citizens' attitudes to the welfare state have been quantitative, relying on large- $\mathrm{N}$ attitude survey data collected using standardised questionnaires with answers given in fixed categories. While this approach's strength is the broad and representative overview of the factors that correlate with respondents' attitudes to specific issues, its main weakness is the limited scope for revealing the reasoning and motivations behind the attitudes expressed by the survey participants. By contrast, the primary contribution of the methodological approach adopted in this study is its ability to give insights into ordinary citizens' reasoning and arguments about political issues, even though we are unable to make strong claims about the representativeness of the findings. A further added value of the approach is that we are able to present qualitative data that are comparable cross-nationally, which is rarely the case with such data. The data were obtained from group conversations organised as democratic forums or mini-publics held in Germany, Norway, Slovenia and the United Kingdom. These countries represent contrasting types of welfare mixes 
or regimes (e.g., Taylor-Gooby et al., 2017; Esping-Andersen, 1990; Evers and Wintersberger, 1987). Hence, we are able to explore the extent to which views on welfare for the elderly vary across different welfare regimes - social democratic (Norway), liberal (UK), conservative-corporatist (Germany) and post-socialist (Slovenia).

The paper is structured as follows. In the next section, we describe the key structural and institutional changes related to population ageing and the provision of social protection and care for the elderly, indicating the important changes in responsibility of the state and existing differences between the four observed countries. Section three outlines empirical results from a comparative analysis based on transcripts from democratic forums in the four countries. We show differences and similarities in reasoning and argumentation concerning welfare state responsibility for providing for older people, where expectations seem to be quite different regarding the future of the state and family as well as individual's own responsibilities. In the final section, we summarise and discuss the main findings.

\section{POPULATION AGEING AND WELFARE STATE RESTRUCTURING}

The comparative welfare state literature demonstrates how welfare states have been restructured due to demographic changes, new social risks as well as global and economic influences, most notably the recent financial and economic crisis (Taylor-Gooby et al., 2017; Hemerijck, 2013; Taylor-Gooby, 2013; Farnsworth and Irving, 2011). In many countries, government responses to these societal challenges have been strongly influenced by the paradigm of neoliberalism, which refers to increased marketization, the individualisation of risks and responsibility for welfare, social policy retrenchment and an increased emphasis on targeted and means-tested measures (Mau, 2015; van Kersbergen et al., 2014; Taylor-Gooby, 2013). Research on the shifting responsibility for welfare stresses the withdrawal of the state and an expanding role for the market, the family and civil society. Mau (2015) points out that socio-structural changes, in particular individualisation and marketization, have brought the increasing acceptance of inequality, along with greater scepticism of redistributive measures in the last 25 years.

In response to population ageing, there have been distinct paradigm shifts in social policies for the elderly. One such shift is the change in emphasis from early retirement to active ageing and incentives to work longer (conversely, disincentives to exit early) (Boudiny, 2013; Ebbinghaus and Hofäcker, 2013). Another important shift has been from state pension systems that promise to replace a certain level of previous income (known as the defined-benefit principle) to systems in which the contribution rate is fixed (aka defined-contribution pensions). In the latter case, the eventual benefit level depends on parameters including cohort life expectancy, the chosen age of retirement, and the overall amount of contributions paid during one's working career. As a result, public old-age pensions are more uncertain for future generation retirees. The degree of uncertainty in a given country is influenced by factors such as the pace of demographic ageing, the size of the active population and the extent to which policy reforms have already been successfully implemented to address contemporary economic and demographic pressures. Modern welfare states differ considerably in this regard.

Moreover, in the area of elderly care the different roles of the state, the market, the family and the civil society organisations across countries have led to varying levels of (de-/re) familialisation, i.e. the degree to which family is responsible for care, 
forming specific welfare regimes (Borsenberger et al., 2016; Ganjour and Widmer, 2016; Haberkern and Szydlik, 2010; Saraceno and Keck, 2010; Bettio and Plantenga, 2004; Leitner, 2003; Daly, 2002; Daly and Lewis, 2000). Scandinavian countries have over a long period seen strong de-familialisation with regard to elderly care, i.e. state offering highly developed care institutions, programmes and support measures, while Southern European countries and Eastern European countries still largely depend on the family to take care of the elderly (Kalmijn and Saraceno, 2008; Haberkern and Szydlik, 2010; Österle, 2010). In recent years, austerity measures have altered the relationship between the state and the family. In many countries, the de-familialisation trend has halted and in others there are signs of a move towards re-familialisation, e.g. by subsidising domestic care or enabling individual choice by cash-for-care schemes (Ungerson, 2004; Da Roit et al., 2007; Pavolini and Ranci, 2008; Eichler and Pfau-Effinger, 2009; Yeandle et al., 2012; Deusdad et al., 2016). The increasing care needs (along with tighter budget constraints) are responded to in numerous ways, including withdrawal of the state and a stronger role for market players as well as other solutions, e.g. the growing involvement of migrant workers, especially in Italy (Shutes and Chiatti, 2012). Overall, there is considerable variation in the way welfare states have responded to the pressures of demographic change and economic crises.

The differences across our selected case countries in the areas of old-age pensions and elderly care are significant. Germany represents the conservative corporatist regime with old-age pensions coupled to occupational status and long-term care needs covered by mandatory public or private insurance. The literature has characterised the care system as "supported familialism" (Haberkern and Szydlik, 2010). Norway belongs to the social democratic welfare regime. There is a universal public oldage pension system, which awards benefits based on past wage contributions and a poverty-preventing basic pension for individuals with low or no contributory entitlements. The comprehensive public long-term care system is leading to a strong degree of de-familialisation (Leitner, 2003; Saraceno and Keck, 2010). Slovenia as representative of Central and Eastern European countries has a pay-as-you-go pension system based on past wage contributions, with set minimum and maximum pensions, and a less developed long-term care system placing a high degree of responsibility on the family (Chung et al., 2018). The UK fits the description of a typical liberal welfare regime. Individual responsibility and market provision play a key role in both old-age pensions and long-term care (Saraceno and Keck, 2010).

Since the elderly are generally perceived as highly deserving of assistance from the welfare state (van Oorschot, 2000; Svallfors, 2010), we may anticipate that people will favour a strong role for the state in supporting pensions and care for older people. Such expectations are reflected in public opinion surveys. For instance, in all four countries more than 90 per cent of respondents perceive home care and institutional care for the elderly to be a responsibility of public authorities (Eurobarometer, 2007: 66). However, people's attitudes are also heavily influenced by the institutional context or 'regime socialisation' and by different norms and expectations regarding the roles of the family and the state (Ganjour and Widmer, 2016; Chung and Meuleman, 2017). Thus, we are likely to find considerable variation in attitudes to different actors' roles in the future welfare policies aimed at the elderly in the four countries. We expect people to demand more from the welfare state in Norway (regarding pensions as well as long-term care) while having lower expectations in the UK that emphasise mar- 
ket solutions and self-reliance. Germany and Slovenia are likely to be located in the middle. In Slovenia, we anticipate strong calls for public regulation alongside the continued prominent the role of the family in elderly care, while in Germany there might be a greater stress on the role of the market as well as self-reliance, although not as pronounced as in the UK.

\section{THE FUTURE PROVISION OF WELFARE FOR THE ELDERLY: VIEWS FROM DEMOCRATIC FORUMS}

The paper relies on qualitative data collected from democratic forums conducted in four European countries - Germany, Norway, Slovenia and the United Kingdom. The democratic forums took the form of two full-day sessions, including conversations among ordinary citizens, who discussed what should be the welfare state's future priorities, in a plenum and in smaller groups (breakout groups). The democratic forums were carried out in autumn 2015 and may be described as mini-publics of 34-37 people of different genders, ages, ethnicities, occupations and political orientations. ${ }^{1}$ In contrast to top-down approaches like pre-designed surveys, structured interviews or focus groups, the forums represent a 'bottom-up' research strategy that allows an inquiry into the priorities of individuals with much less bias towards issues identified a priori by academic researchers. This enables researchers to examine the process of discussion and potential attitude formation (Taylor-Gooby and Leruth, 2018). Thus, with the help of full transcripts of the

${ }^{1}$ In all the examined countries common recruitment criteria were used and the forums included a broadly representative sample of the population, consisting of older and younger, middle and working class, women and men and those with and without dependent children, as well as some unemployed, self-employed, retired, ethnic minority and immigrant members (Taylor-Gooby and Leruth, 2018). forum discussions, which were coded in the qualitative data analysis software Nvivo11, we performed a systematic analysis of the participants' arguments. The analysis focused on a comparison of similarities and differences in citizens' attitudes and future expectations with regard to two dimensions of social protection of old people: (1) oldage pensions; and (2) care for the elderly.

\section{People's views on the future of pension systems}

The topic of state responsibility concerning old-age pensions in Germany was closely interwoven with a discussion of unconditional basic income, an idea that many forum participants supported as a goal for future policy. However, there was considerable uncertainty as to how that could work in practice. The main disagreement centred on the question of conditionality. Should the award of the basic income allowance be completely unconditional or should the system incorporate some kind of recognition of work prior to retirement (i.e., in the form of an increased allowance)? The following two extracts illustrate how the participants linked the topic of income security in old age with the need for a state-funded basic income:

It's a matter of the taxes necessary to support the system going forward, and that many people don't have the income to be able to pay into the system in the first place. One possibility is that you have a basic retirement support income for everyone who's worked... (DE male, age 65+)

An unconditional basic income is the long-term goal because, looking at the current situation, it seems that we're not headed toward a comprehensive public pension, since that can't be financed, but rather the current generation bears both the current retirees and their own costs as well. This time period must be 
subsidised by the state because, if it's not, it can't work. (DE, male, age 65+)

Against this background, in Germany there was also a widespread sentiment that private pension investments would become even more necessary in the future. The participants did not seem to believe that the state alone could manage to provide adequate pensions in the future. As far as the welfare mix is concerned, the market would play a more prominent role as a provider of retirement income and, thus, individuals would have to take a greater degree of responsibility for their own income in old age. It should be noted that these statements expressed what people expected rather than their actual preferences if able to choose freely. The statement below exemplifies this pessimistic view of future state pensions:

People are saying that no one can live from this pension anymore anyway. Everyone should invest in a private retirement fund and, if possible, two or three because who knows how bad inflation will become. (DE male, age 25-34)

Another observation that stands out from the German democratic forum is the distrust in the federal state's ability to manage workers' contributions responsibly. One discussion in the breakout groups on the first day illustrates this point.

A major problem is that this is not at all transparent. Money is paid in, and you don't know where it goes [...]. The whole issue is opaque and therefore uncertain. That's why people have so much fear in this regard. (DE female, 25-34)
This lack of trust in the state and the feeling the system is not sufficiently transparent is similar to what we observe in the UK data. The UK pension system has undergone important changes in recent years, with the old and new systems currently operating side by side. ${ }^{2}$ It is not possible to opt out from the new state pension, which, being more generous than the old basic state pension, provides a better safety net and protection against poverty. As a replacement for the additional state pension, after 2018 all employers must provide automatic enrolment in a workplace pension scheme. The discussion in the UK reflected some uncertainty and confusion about the new rules, which is not surprising given that the transition to the new system is still ongoing.

Several of the UK forum participants wondered whether their national insurance contributions would lead to adequate pensions when they retire.

I actually think in maybe 25 years' time there may not be a state pension for our generation. [...] We may have to make our own provision. [...] Because of the cost. [L]ittle emphasis has been put on state pension, it's about you as an individual, what you're doing, you know, long term. And I think that's what's going to possibly be encouraged in the future. (UK male, age 45-54)

Moreover, they expressed considerable mistrust in the state's ability to efficiently and responsibly manage the large amounts of workers' pension contributions paid into the system. Further, they lamented the lack of transparency and were afraid that the

\footnotetext{
${ }^{2}$ Depending on whether you are born before or after 6 April 1951 for men and 6 April 1953 for women, you are subject to a different set of pension eligibility rules. Workers born before the mentioned dates are entitled to the basic State Pension and generally also the earnings-related Additional State Pension (unless they have contracted out). Individuals born after these dates can claim the flat-rate new State Pension when they reach the State Pension age, while the Additional State Pension has been abolished. A full State Pension now requires 35 years of National Insurance contributions (see https://www.gov.uk/new-state-pension).
} 
money would just disappear in the 'cauldron'. We also recognise such views in the German discussion, but they were voiced more strongly in the UK case, as exemplified by the following statement.

Yeah, but the government doesn't give us enough information. It's very sensitive, you know, giving that out. And I'd like to know where the money goes. We pay our council tax, and each year we get a bill come through, and it tells what percentage goes to where, like that, with the education, the pension, the NHS, just each, you know. (UKfemale, age 45-54)

Apart from a lack of confidence in the government, we also find another argument for making more investments in private pensions in the UK. Several statements hinted at the need to relieve the financial load on the government, giving rise to the suggestion that high-income earners should perhaps not receive the state pension. Private pensions were seen as a solution to ease the burden on government spending.

It could be more mandatory, some sort of policy for private pensions, to take the pressure off the government, so there's more businesses (that) have to provide private pensions. (UK male, age 25-34)

Yet it should be noted that when the moderator pushed the participants to think about which policies they would prefer to see in the future rather than what they actually expected to happen, several participants argued it was necessary to continue some kind of state pension, at least for persons who have contributed to the system.

You'd think we'd have to [keep the state pension], because just because you haven't been able to save doesn't mean you haven't worked and paid into the system for your entire working life. (UKfemale, age 35-44)
By contrast, in Slovenia the responsibility and role of the state emerged as a key element in the participants' ideas of the future. It was seen as central for guaranteeing a decent standard of living for the elderly.

Let's look at the role of the state in this area, care for the elderly, the state should take over the role of the guarantor, I mean in a way that it should guarantee each elderly person a decent pension. [...] (SI male, 35 years old).

In short, the state should provide not only basic security but also care services and adequate cash benefits and subsidies. It should fulfil several roles, such as guarantor (as the quote above directly illustrates), organiser, co-founder and redistributor (to achieve lower inequality). This general understanding is strong in Slovenia and rooted in the country's socialist past. Despite the transition to a market economy, Slovenians would like the state not only to safeguard certain basic welfare benefits to marginalised groups but also to adopt a more all-encompassing role of responsibility for the well-being of its citizens. One may argue that this description would fit the Norwegian welfare state as well, but there was a clear difference in discourse. Notably, Slovenia was the country in which the participants voiced the strongest complaints about the current public pension system's level of generosity.

You need to work because your pension is too low, that's right. [...] You see, pensions have actually been lowered so much from 2000, from the beginning of 1 January onwards, that the elderly are forced to work, actually, because they cannot survive... (SI female, age 59)

Moreover, as the following statements illustrate, some participants expressed fears that public pensions would be less generous or even disappear in the future, which was a relatively common concern in all countries. 
Pensions will not be paid, because nobody will contribute into the fund. (SI female, age 36)

For us, it's not even certain that we'll live to receive them. (SI female, age 38)

The discontent and pessimism related to the current and future levels of public pensions led to quite vocal calls for a minimum guaranteed pension.

Start with the pensions. To have a guaranteed minimum pension. (SI female, age 44)

[T] his is now rapidly getting worse, in general, those who retired much earlier have a normal pension and it makes $a$ bit of a difference, every next person retiring now is worse off. [...] For those coming now, it'll only get worse and worse. That's not fair. (SI female, age 59)

Reasons for a guaranteed minimum pension sufficient to ensure an adequate living standard included poverty prevention, increased consumption, which would help the economy, and better health among the elderly.

[...] basically, if we had this minimum guaranteed pension, then the poorest pensioners [...], they wouldn't need to do additional work to survive, I don't know, usually there's also undeclared work, pensioners need to go [...] to be cleaners and such, so they survive. Then there'd be fewer pensioners slipping below the poverty threshold and that would be positive, because they'd be, they'd be able to afford better food, more quality [...]. (SI female, age 44)

Also in Slovenia, there was mention of the need to take some individual responsibility for one's own retirement income, therefore seeing private pensions as a possible solution. However, several participants questioned the extent to which one could realistically expect individuals with a low income to pay additional, private pension contributions.

One more thing, right. We'd probably also need to save something ourselves. [...] Absolutely. The state will never be able to do absolutely everything. (SI male, age 67)

[...] The other thing is additional pension insurance, which some are paying into pillar pension schemes, or make savings, investment savings, or something - it's something those with a high income are able to afford. And they will have more to draw on. [...] But someone on a minimum wage could not put anything aside to make extra savings. (SI female, age 49)

Moreover, the lack of transparency in the management of private pension funds was considered a problem and made some participants afraid their private contributions would not be managed in a responsible and efficient way. This reluctance to embrace private pension savings distinguishes the Slovenian discussions from the other countries.

It's the state, the state that should oversee these funds, madam, not the insurance company. (SI male, age 67)

For example, I don't trust the Blue insurance company at all. (SI female, age 47)

Unlike the three other countries, in Norway much of the discussion on old-age pensions centred on the questions of the retirement age and how long people should be expected to work in the future. Making people retire later was the main policy priority in response to population ageing. With regard to burden-sharing and the issue of who should be responsible for ensuring an adequate income in old age, there was 
quite a strong emphasis on the need to take greater individual responsibility for one's retirement income.

We identify two rationales underlying most of the statements in favour of more individual responsibility. On one hand, some participants seemed to think there is a limit to what one can reasonably expect from the Norwegian state which, compared to most other countries, takes good care of its residents by providing a comprehensive range of cash and in-kind services. Hence, it was reasonable to ask individuals to take greater responsibility for their own income security in old age to alleviate the burden on the state. As opposed to what we have seen in the other countries, this discourse did not have distrust in the state's current or future ability to manage pensions as its main motivation.

You cannot put all of the responsibility onto the state and say that we don't believe people are capable of saving for themselves, so we will save for them. (NO female, age 44)

Save privately too. [...] Who is responsible for your life? Is it you or is it the state? It is an awful lot that the state should take responsibility for. (NO female, age 44)

Moreover, several statements pointed to the need for more private investments owing to the increased financial pressures on the state and the necessity to reduce the generosity of public pensions due to an ageing population. This logic was similar to that identified in the German and UK data. The following statements illustrate the widespread belief that the current level of state pension benefits would be difficult to maintain.

I don't think one has taken enough responsibility in respect of saving for the future. [W] don't think of these things because it is such a long time ahead, right? But the whole point is that a system like this could change rather drastically, and we have to change the pension system rather drastically, because we can't afford it. Then it is even more important [...] to secure your own old age. (NO female, age 44)

In the Norwegian case, there was a striking absence of arguments that explicitly articulated a stronger state responsibility for basic or minimum old-age pension benefits. Obviously, it is impossible to state with certainty why particular views were not voiced in the discussions. In our view, one plausible interpretation is that the participants took for granted that there would be continued state involvement in this regard. Opinions might differ more strongly concerning the use of means-testing to target public old-age pensions only to those who need it the most rather than giving everyone access to the public system, as is currently the case. However, since Norwegians generally have a high degree of trust in the state, they typically do not see state involvement as a problem per se.

\section{People's views on the future of elderly care}

In this section, we focus on the attitudes to care for the elderly - an issue most prominent in the Slovenian case. Elderly care was less discussed in the UK, Germany and Norway.

In Slovenia, the family is the main provider of elderly care, and there is a tradition of institutional care (Mali, 2010; Hlebec et al., 2012; Filipovič Hrast et al., 2014). This was reflected in discussions, which revolved around the poor accessibility and high cost of institutional care for the elderly. The most commonly proposed solution for this was to increase pensions, in particular the minimum pensions, indirectly suggesting that it should be the state's responsibility to make care for the elderly more accessible. 
[T] he home for the elderly costs EUR 1,500 for people who are chained to the bed. I think that is the price. So, the person should receive a EUR 1,500 pension, end of story. (SI male, age 44)

Care is framed as an individual social (normative) right underpinned by the view of old people are as deserving given their past contribution to society. Thus, the state is responsible for guaranteeing these rights.

If one is active for 40 years, or not due to incapacity to work or whatever other reason, but contributes in a certain way and there is so much money involved here that access to a home for the elderly should not be an issue. But it is. And that's what worries me. [...] I think our government should be ashamed of itself. (SI male, age 44)

Beyond decent pensions or subsidies that make the purchase of care for poor elderly affordable, the state's responsibilities should also include the organisation of home-care services, and even socialising to ensure the social inclusion of the elderly, as the following quote illustrates:

That's why the state needs to visit them (the elderly) and check up on them every 5 years. (SI male, age 45)

Even though the state should assume the main responsibility for care, the role of the family was also recognised. However, participants frequently noted many families' limited ability to offer care due to factors like work obligations or a lack of financial resources to take care of an older person.

Also in the UK there was a perception that the elderly deserve access to good quality care, although this was most commonly linked to the individual's responsibility to ensure this care. The use of housing assets was a commonly mentioned way of achieving this.
And, of course, they have to sell their houses to pay for their own care (UK female, age 35-44).

Another way to assume individual responsibility, which emerged in the UK discussions, was to prevent care needs by looking after your health. In this sense, a partial role of the state was recognised in terms of stimulating healthy behaviour, e.g., a sugar tax was mentioned.

As expected based on current institutional characteristics, in the UK, care was therefore seen chiefly as an individual responsibility, to be ensured through private savings and the liquidation of assets, and partly as a family responsibility. In this context, some participants highlighted the need for leave from work to take care of sick or frail older family members. However, the issue was contested, since such leaves might interfere with the needs of employers and work-life balance issues.

Why should you be paid to leave work to go and look after your family members when they are most likely going to be entitled to have a carer anyway? So why not give another person the job instead of you leaving your job to go and do another job temporarily and be paid at the same time. [H] ow is that fair for the employer? (UK female, age under 24)

In general, the discussions in the UK were quite different from those in the other countries, especially in Slovenia, indicating a liberal and highly individualised approach to welfare with much less emphasis on state responsibility. There was a negative perception of growing care needs, seeing this as a sign of a poor (and meaningless) life. Some participants even argued that it should be possible to refuse care and have the legal right to euthanasia.

All it was is, erm, getting older. I would like to have...and this would affect the 
figures... I would like to have the right to die when I want to die. And that will affect a lot of people, 'cos it would save a lot of money on care, on the NHS, it would save a lot of money, and a lot of people would like to have the right to die when they choose. Without somebody being prosecuted for assisting your [...]. (UK female, age 45-54)

A little controversial, but you could legalise assisted suicide for people who think, well, I've had a good innings, I'm 85, I don't want to be here anymore. (UK male, age 25-34)

Discussions in Germany also recognised the family as an important actor in elderly care, similarly as in Slovenia, through either actually doing the care work or aiding in paying for formal care provisions, such as care homes, where the issue of the affordability of care was mentioned. At the same time, participants criticised the absence of the family, seeing it as a negative trend in society.

And from the human perspective, I think every parent normally would give and do anything for their child, and when then in old age you're left totally alone and your children don't look after you, I think that is unbearably sad, in addition to the financial burden on top of everything else. It used to be different, when everyone cared for everyone else, maybe 20 years ago. That's not so long ago. (DE female, age 33)

In Germany, individual responsibility was evident in discussions on private care insurance as an addition to state funding, yet there was no agreement among the participants on whether payment of this insurance, similar to tax payments, should be earnings-related. Overall, nursing care was primarily seen as a state responsibility. The state's role was therefore emphasised with regard to the financing of care.
Further, the diminishing role of family care was seen as one reason for the state's increased responsibility in providing or paying for care.

(...) the state will encounter certain limits, because more institutions will be needed, because the family is not in a position to care for these older people because of the living situation or if the family doesn't live here in Berlin but far away, or why should I quit my job in order to care for my mother or whatever. These are different conditions, different social requirements we have today, and it's a question of how elderly people find themselves cared for and attended to. (DEfemale, age 66)

Interestingly, the notion of the state increasingly taking over the provision of care was perceived as a double-edged sword. The state has assumed many tasks that were once taken care of by the family, reducing the demands on the latter. However, maybe something is being lost along the way in terms of within-family intergenerational solidarity.

I think it's a problem that people don't need children anymore. That has to do with distribution and old age care, nursing care, pension...when you look at China, [...] in the little villages, they know that they're dependent on their family, that they take care of me, and the children grow up with this belief, so that is a question - whether the state is taking something away from us by taking care of us, because people don't need children anymore. It's too stressful, it's hard to balance it with work. I don't need them for old-age security and care. It used to be that the family was your old-age security, and that has been removed by this social welfare system. It's no longer necessary. (DE female, age 29) 
In both Germany and Norway, the preference for an increased role for the family was articulated, for instance, through the idea of multigenerational households, proposed as a solution for the growing care needs also in relation to childcare.

I think the support of multigenerational households is always a very good thing because then you can also address the nursing care issues when you have multigenerational households. If many generations live in one household, you can support or provide for more living space, then maybe it would be nicer to have the grandchildren take care of their grandmother rather than someone else (DE male, age 55).

In Norway, overall, much of the discussion centred on how the government could take less responsibility than it does today. A liberal market perspective was present among the Norwegian participants, contrasting especially with Slovenian attitudes. The Norwegians showed signs of a market-oriented reasoning that underscored the cost of social welfare and that someone has to bear these costs. To some extent, everybody should be responsible for his or her own life, not the state. In the discussions, the main argument for the state taking less responsibility was the belief the welfare state will not manage the economic cost.

I don't believe society will be able to meet the requirements we are facing. (NO female, age 70)

The importance of the family was also recognised in Norway. There was a perception that family members and friends give the best care - better than what the government can provide - and they offer a more realistic solution given the current challenges to welfare state sustainability. In this regard, there were parallels to the discussions in Germany.
[W]hat I mean is we here in Norway, we aren't that extended family that you find in other cultures. We have sort of made the responsibility of caring for the elders public, and the government will never be as caring as the family and friends. It is really sad, but it is a reality. If we push care over onto the government, the government will answer 'This is the care you get for your money' and they would rather use it for health and prioritising and such. The public can never give as good care as we can do as family and friends. It's just the reality. (NO male, age 34)

Contrary to Slovenia for example, in Norway the market was seen an acceptable solution with respect to future care issues, albeit complementing more than replacing the state. One possible reason for this divergence is the focus on individual responsibility we found in Norway. Therefore, this was more similar to the UK discussions, although in the UK paying for care in the market was perceived as paramount.

\section{CONCLUSION}

This article has addressed people's views and perceptions regarding the future of welfare policies for the elderly, focusing on the welfare mix in four countries that represent different welfare state and care regimes. The results of the article therefore shed light on how people under different institutional arrangements understand future developments regarding the provision of welfare for the elderly. The findings accentuate some expected differences and show some interesting similarities among the four countries observed - the UK, Norway, Germany and Slovenia.

Given the qualitative nature of the data and methods used in this study, we do not make any strong claims about the generalisability of the findings. The samples in each 
country were based on common recruitment criteria and included a diverse group of people to capture a variety of opinions, likely to reflect to some degree the population at large. Yet, the sample sizes were too small and individual variation too large to allow for the use of quantitative methods with a view to performing stringent hypothesis formulation and testing. Especially in larger countries, like Germany and the United Kingdom, it may have affected the findings that the forum participants were recruited from the same, geographical setting. Moreover, the views expressed by the participants tended to reflect their expectations and views about future policies more than what they actually wished that institutions would be like. A common feature of the forum discussions across the four countries was that these views and expectations were clearly rooted in and shaped by the past and current institutional and economic context. Thus, only to some degree the data offer insights into people's policy preferences. Nonetheless, the democratic forums have improved our understanding of how institutions shape citizens' expectations of future state welfare for the elderly and their reasoning related to these. The data also reveal interesting cross-country differences and similarities in citizen's expectations. Further research should assess potential explanations and political and social implications of these cross-national patterns.

As expected, the current institutional settings were reflected in the views of the forum participants, which, despite being future-oriented draw from their current experiences and institutional settings. Consequently, the role of the market was most pronounced in the UK, but also quite strong in Germany and Norway. In the latter case, we had anticipated a stronger emphasis on the state. Instead, it appears that the setting of limits on state responsibility was more often discussed in the context of the Norwegian system, in which people were used to the state assuming considerable responsibility for welfare policies for old people. Interestingly, in Norway the participants' future preferences were in the direction of less state responsibility and a stronger role for the family as a solution in a highly individualistic society, where the welfare state has long promoted labour market participation over traditional family obligations. Hence, increasing family responsibility or familialism in elderly care was not perceived by the participants as a negative trend or a consequence of austerity measures, but as something that had been forgotten in a society in which the state has assumed a comprehensive role in giving access to formal care.

A partly similar discussion was found in Germany where the lack of family care was seen as a negative trend and something that should perhaps be more stimulated, by e.g. supporting multigenerational households. This is in line with what Daly (2002) perceives as one of the ironies of contemporary welfare states, since "the welfare states are now required to call forth a form of solidarity, which their own practice has helped to diminish" (Daly, 2002: 260). In Slovenia, in line with the current system, strong state involvement was preferred in the respondents' views, although the role of the family was also emphasised relative to elderly care. However, as elderly care still relies substantially on the family, the increased role of the state in ensuring access to care was seen as important, and the limits of family care were recognised and discussed. In the UK, de-familialism and individualism seem to be strongly integrated into people's attitudes as a norm. Discussions also mentioned more radical solutions, even including the 'right' not to receive care, which seems consistent with individualistic and liberal approaches, but could also be linked to potentially reluctant individualism (Taylor-Gooby, 2018a), understood as individualism due to a lack 
of other choices. We can therefore conclude that current institutional settings were reflected in the discussions on what was expected of the welfare state in the future, while the welfare state's constraints were recognised to different degrees across the countries.

In all four countries, the discussions on future welfare of the elderly were linked to sustainability issues and financing of the welfare state. Therefore, as expected, the need to contain costs in the context and aftermath of the great recession and the increasing demographic pressures was both acknowledged and accepted. However, this was more pronounced in the UK, as well as partly Norway and Germany. It was much less explicit in Slovenia, even though it faces stronger demographic pressures than the other countries and was the one hit hardest by the recession (Filipovič Hrast and Rakar, 2017; Eurostat, 2018).

The partial withdrawal of the state appeared to be expected in all countries, especially in relation to ensuring sufficient pensions. The future role of public pension provision would most likely be to provide a basic safety net. Slovenia is an exception here. In Slovenia, the state remained centre stage of the discussions, with some participants suggesting it should play an even stronger role. Overall, the state's main role was to ensure sufficient means (decent pensions) and provide care. In Germany, the UK and Norway, greater emphasis was placed on additional individual responsibility for one's well-being and the need to unburden the state. Other arguments for the withdrawal of the state, along with the financial sustainability issues, seemed to be a distrust in the state's management, with participants therefore emphasising a bigger role for the markets (e.g. private pensions, private providers of care). In this, we can see a reflection of the neoliberal paradigm. However, in Slovenia the role of the market was seen as suspicious. We can again perhaps connect this to the country's socialist past and distrust of capitalism, along with perceptions that private solutions exacerbate inequalities because they are not equally accessible to all. Another reason might be that the pressures the recession placed on the everyday lives of people (higher unemployment and stagnating incomes) have made Slovenian more reluctant to look at individual and private solutions for the future welfare of the elderly and again made them turn more towards the state. In the three other countries, it seems that the limits of the welfare state were more readily recognised and other privately oriented, to a varying degree complementary, solutions were seen as viable and (at least to some extent) acceptable options for the future.

\section{Acknowledgements}

The authors acknowledge the financial support from the Slovenian Research Agency (research core funding No. P5-0200) and the NORFACE grant as part of the Welfare State Futures programme (grant number 462-14-052).

\section{REFERENCES}

Ascoli, U., \& Ranci, C. (Eds.). (2002). Dilemmas of the welfare mix. The new structure of welfare in an era of privatization. New York: Kluwer Academic.

Bettio, F., \& Plantenga, J. (2004). Comparing care regimes in Europe. Feminist Economics, 10(1), 85-113. https://doi.org/10.1080/1354570042 000198245

Borsenberger, M., Fleury, C., \& Dickes, P. (2016). Welfare regimes and social cohesion regimes: Do they express the same values?. European Societies, 18(3), 221-244. https://doi.org/10.108 $0 / 14616696.2016 .1172717$

Boudiny, K. (2013). 'Active ageing': from empty rhetoric to effective policy tool. Ageing and Society, 33(6), 1077-1098. https://doi.org/10.1017/ S0144686X1200030X

Chung, H., Filipovič Hrast, M., \& Rakar T. (2018). The provision of care - whose responsibility and 
why?. In P. Taylor-Gooby \& B. Leruth (Eds.), Attitudes, Aspirations and Welfare. Basingstoke: Palgrave Macmillan.

Chung, H., \& Meuleman, B. (2017). European parents' attitudes towards public childcare provision: The role of current provisions, interests and ideologies. European Societies, 19(1), 49-68. https://doi.org/10.1080/14616696.2016.1235218

Da Roit, B., Le Bihan, B., \& Österle, A. (2007). Longterm care policies in Italy, Austria and France: Variations in cash-for-care schemes. Social Policy \& Administration, 41(6), 653-671. https://doi. org/10.1111/j.1467-9515.2007.00577.x

Daly, M. (2002). Care as a good for social policy. Journal of Social Policy, 31(2), 251-270. https:// doi.org/10.1017/S0047279401006572

Daly, M., \& Lewis, J. (2000). The concept of social care and the analysis of contemporary welfare states. The British Journal of Sociology, 51(2), 281-298. https://doi.org/10.1111/j.14684446.2000.00281.x

Deusdad, B. A., Pace, C., \& Anttonen, A. (2016). Facing the challenges in the development of long-term care for older people in Europe in the context of an economic crisis. Journal of Social Service Research, 42(2), 144-150. https://doi.or $\mathrm{g} / 10.1080 / 01488376.2015 .1133147$

Ebbinghaus, B. (2011). The varieties of pension governance. Pension privatization in Europe. Oxford: Oxford University Press.

Ebbinghaus, B., \& Hofäcker, D. (2013). Reversing early retirement in advanced welfare economies. A paradigm shift to overcome push and pull factors. Comparative Population Studies, 38(4). https://doi.org/10.12765/CPoS-2013-24en

Ebbinghaus, B., \& Whiteside, N. (2012). Shifting responsibilities in Western European pension systems: What future for social models?. Global Social Policy, 12(3), 266-282. https://doi. org/10.1177/1468018112455655

Eichler, M., \& Pfau-Effinger, B. (2009). The 'Consumer Principle' in the care of elderly people: Free choice and actual choice in the German welfare state. Social Policy \& Administration, 43(6), 617-633. https://doi.org/10.1111/j.14679515.2009.00684.x

Esping-Andersen, G. (1990). The three worlds of welfare capitalism. Cambridge: Polity Press.

Esping-Andersen, G., \& Myles, J. (2006). Sustainable and equitable retirement. In G. L. Clark, A. H. Munnell \& J. M. Orszag (Eds.), The Oxford Handbook of Pensions and Retirement Income. Oxford: Oxford University Press.
Eurobarometer. (2007). Special Eurobarometer 283/ Wave 67.3 - TNS Opinion \& Social Health and long-term care in the European Union report. Brussels: TNS Opinion \& Social.

Eurostat (2018). Database [data file]. Available at http://ec.europa.eu/eurostat/data/database

Evers, A., \& Wintersberger, H. (1987). Introduction. In H. Wintersberger, H. Nowotny \& A. Evers (Eds.), The changing face of welfare. Aldershot: Gower.

Farnsworth, K., \& Irving, Z. (2011). Responding to the challenges: Some concluding remarks on welfare futures in changed circumstances. In K. Farnsworth \& Z. Irving (Eds.), Social Policy in Challenging Times. Bristol: Policy Press.

Filipovič Hrast, M., Hlebec, V., Knežević Hočevar, D., Černič Istenič, M., Kavčič, M., Jelenc-Krašovec, S., Kump, S., \& Mali, J. (2014). Oskrba starejših v skupnosti: dejavnosti, akterji in predstave. Ljubljana: Fakulteta za družbene vede, Založba FDV.

Filipovič Hrast, M., \& Rakar, T. (2017). The future of the Slovenian welfare state and challenges to solidarity. In P. Taylor-Gooby, B. Leruth \& H. Chung (Eds.), After austerity: Welfare state transformation in Europe after the Great Recession (pp. 115-135). Oxford: Oxford University Press.

Ganjour, O., \& Widmer, E. D. (2016). Patterns of family salience and welfare state regimes: Sociability practices and support norms in a comparative perspective. European Societies, 18(3), 201-220. https://doi.org/10.1080/14616696.2016.1158846

Haberkern, K., \& Szydlik, M. (2010). State care provision, societal opinion and children's care of older parents in 11 European countries. Ageing and Society, 30(2), 299-323. https://doi. org/10.1017/S0144686X09990316

Hemerijck, A. (2013). Changing welfare states. Oxford: Oxford University Press.

Hlebec, V., Filipovič Hrast, M., Kump, S., Jelenc-Krašovec, S., Pahor, M., \& Domanjko, B. (2012). Medgeneracijska solidarnost v Sloveniji. Ljubljana: Fakulteta za družbene vede.

Immergut E. M., Anderson K. M., \& Schulze I. (2007). The Handbook of West European pension politics. Oxford: Oxford University Press.

Kalmijn, M., \& Saraceno, C. (2008). A comparative perspective on intergenerational support. European Societies, 10(3), 479-508. https://doi. org/10.1080/14616690701744364

Leitner, S. (2003). Varieties of familialism: The caring function of the family in comparative 
perspective. European Societies, 5(4), 353-375. https://doi.org/10.1080/1461669032000127642

Mali, J. (2010). Social work in the development of institutional care for older people in Slovenia. European Journal of Social Work, 13(4), 545559. https://doi.org/10.1080/13691450903403784

Mali, J. (2017). The cultural context of long term care. In H. Rogers (Ed.), Social Work. New York: Nova Science Publishers.

Mau, S. (2015). Inequality, marketization and the majority class: Why did the European middle classes accept neo-liberalism?. Basingstoke: Palgrave Macmillan.

Pavolini, E., \& Ranci, C. (2008). Restructuring the welfare state: Reforms in long-term care in Western European countries. Journal of European Social Policy, 18(3), 246-259. https://doi. org/10.1177/0958928708091058

Rostgaard T., \& Zechner M. (2012). Guest editorial: Shifting boundaries of elder care: Changing roles and responsibilities. European Journal of Ageing, 9(2), 97-99. https://doi.org/10.1007/ s10433-012-0231-y

Saraceno, C., \& Keck, W. (2010). Can we identify intergenerational policy regimes in Europe?. European Societies, 12(5), 675-696. https://doi. org/10.1080/14616696.2010.483006

Shutes, I., \& Chiatti, C. (2012) Migrant labour and the marketization of care for older people: The employment of migrant care workers by families and service providers. Journal of European Social Policy, 22(4), 392-405. https://doi. org/10.1177/0958928712449773

Svallfors, S. (2010). Public attitudes. In F. G. Castles, S. Leibfried \& J. Lewis (Eds.), The Oxford Handbook of the welfare state. Oxford: Oxford University Press.

Svetlik, I., \& Evers, A. (Eds.). (1993). Balancing pluralism: New welfare mixes in care for the elderly. Aldershot: Avebury.

Taylor-Gooby P. (2013). The double crisis of the welfare state and what we can do about it. Basingstoke: Palgrave Macmillan.
Taylor-Gooby, P., Chung, H., \& Leruth, B. (2018). The contribution of deliberative forums to studying welfare state attitudes - a United Kingdom study. Social Policy \& Administration, 52(4), 914-927. https://doi.org/10.1111/spol.12405

Taylor-Gooby, P., \& Leruth, B. (Eds.). (2018). Attitudes. Aspirations and welfare. Basingstoke: Palgrave Macmillan.

Taylor-Gooby, P., Leruth, B., \& Chung, H. (Eds.). (2017). After austerity: Welfare State transformation in Europe after the Great Recession. Oxford: Oxford University Press.

Taylor-Gooby, P., Leruth, B., \& Chung, H. (2018). Identifying attitudes to welfare through deliberative forums - the emergence of reluctant individualism. Policy and Politics, 47(1), 97-114. https:// doi.org/10.1332/030557318X15155868234361

Ungerson, C. (2004). Whose empowerment and independence? A cross-national perspective on 'cash for care' schemes. Ageing and Society, 24(2), 189-212. https://doi.org/10.1017/ S0144686X03001508

Van Kersbergen, K., Vis, B., \& Hemerijck, A. (2014). The Great Recession and Welfare State reform: Is retrenchment really the only game left in town?. Social Policy \& Administration, 48(7), 883-904. https://doi.org/10.1111/spol.12063

Van Oorschot, W. (2000). Who should get what, and why? On deservingness criteria and the conditionality of solidarity among the Dutch public. Policy \& Politics, 28(1), 33-48. https://doi. org/10.1332/0305573002500811

Wintersberger, H., Nowotny, H., \& Evers, A. (Eds.). (1987). The changing face of welfare. Aldershot: Gower.

Yeandle, S., Kröger, T., \& Cass, B. (2012). Voice and choice for users and carers? Developments in patterns of care for older people in Australia, England and Finland. Journal of European Social Policy, 22(4), 432-445. https://doi. org/10.1177/0958928712449775 


\title{
Sažetak
}

\section{POREDBENA ANALIZA STAVOVA LJUDI O BUDUĆIM MJERAMA ZA STARIJE OSOBE}

\author{
Maša Filipovič \\ Fakultet za društvene znanosti, Sveučilište u Ljubljani, Ljubljana, Slovenija \\ Mi Ah Shoyen \\ Centre for Welfare and Labour Research \\ Norwegian Social Research (NOVA) Health and Welfare Studies \\ Oslo, Norway \\ Tatjana Rakar \\ Fakultet za društvene znanosti, Sveučilište u Ljubljani, Ljubljana, Slovenija
}

Starenje stanovništva jedna je od najvećih strukturnih promjena koje trenutno utječu na razvoj svih europskih socijalnih država. Različite države se suočavaju s tim promjenama na različite načine. Kao odgovor na svjetsku gospodarsku krizu, mnoge su države reformirale svoje mirovinske sustave i način na koji odgovaraju na rastuće potrebe za skrbi. Te promjene znatno utječu na stavove ljudi o perspektivi socijalne države i na njihova očekivanja u budućnosti vezano uz buduću raspodjelu odgovornosti u pružanju skrbi za starije osobe. Temelj za analizu su podatci prikupljeni u poredbenom europskom projektu uz metodu korištenje demokratskih foruma. Stavove i očekivanja sudionika - kao i razloge $i$ argumente koje su iznijeli - upotrijebili smo kako bismo rasvijetlili čimbenike koji će vjerojatno oblikovati buduće oblike skrbi za starije osobe i mjere mirovinske politike. Analizirali smo četiri države koje imaju različite socijalne režime - Norvešku, Sloveniju, Njemačku i Ujedinjeno Kraljevstvo - i usredotočili se na podjelu odgovornosti između države, tržišta i obitelji, kao i na sličnosti i razlike u prioritetima i proizlazeće argumente iznesene u te četiri države.

Ključne riječi: starije osobe, socijalna država, mirovine, skrb za starije osobe. 